\title{
Work Measurement: \\ Some Research Studies
}




\section{Studies in Management}

General Editor: SAMUEL EILON, D.SC (ENG.), PH.D, D.I.C, M.I.MECH.E, M.I.PROD.E Professor of Industrial and Management Engineering, Imperial College, London

Network ANALysis

for Planning and Scheduling

EXercises in Industrial Management

A Series of Case Studies

Applied Queueing Theory

Mathematical Programming

for Business and Industry
Albert Battersby

S. Eilon, R. I. Hall and J. R. King
A. M. Lee
K. Brian Haley 


\section{Work Measurement: Some Research Studies}

Norman A. Dudley, Ph.D.

Lucas Professor of Engineering Production, University of Birmingham

Macmillan Education 


\author{
MACMILLAN AND COMPANY LIMITED \\ Little Essex Street London, WC2 \\ also Bombay Calcutta Madras Melbourne \\ THE MACMILLAN COMPANY OF CANADA LIMITED \\ 70 Bond Street Toronto 2 \\ ST MARTIN'S PRESS INC \\ I75 Fifth Avenue New York NY Iooro
}

(C) NORMAN A. DUDLEY 1968

Softcover reprint of the hardcover Ist edition 1968 978-0-333-08312-3

First published I968

$9 \times 6,148$ pages

25 line illustrations

LIBRARY OF CONGRESS CATALOG CARD NUMBER 69-IIO72

ISBN 978-1-349-00553-6 ISBN 978-1-349-00551-2 (eBook)

DOI 10.1007/978-1-349-00551-2 


\section{Preface}

In the British Standard Glossary of Terms in Work Study, ${ }^{1}$ work measurement is defined as 'the application of techniques designed to establish the time for a qualified worker to carry out a specified $j o b$ at a defined level of performance'.

This present volume is concerned mainly, but not exclusively, with such techniques; some reference is also made to sampling and other techniques, which may be applied to non-productive periods as well as to productive activity and to vigilance tasks which can be measured more appropriately in terms of mental work load than in terms of the time occupied by visible movements.

In modern productive industry, the practice of work measurement is not only of vital importance, it is also, unfortunately, highly controversial. Work measurement is necessary in order to provide the data required for effective production planning, for estimating costs in advance of production, for cost control purposes and as a basis for worker remuneration where payment by results schemes operate. The controversy which is associated with much work measurement practice may be attributed, in part, to the inadequacy or misapplication of techniques and, in part, to the preoccupation of many work measurement practitioners with financial incentive schemes. Not until the practitioners are regarded as the custodians of the time standards, and are removed from the area of bickering about wage rates, is it likely that any substantial improvement in standards of practice will be achieved.

This volume is not concerned, primarily, with this latter problem. It is concerned with research on work and on techniques of measuring work undertaken in most cases with the object of improving the techniques and their application. For the most part, this research has had, as yet, little impact on industrial practice. This may be due to the conservatism or vested interests of those employing traditional techniques found acceptable over many years of industrial experience, but it may also be due to lack of knowledge of the researches and of their practical implications. It 
is with the object of presenting a review of work measurement research with which the author has been associated, paying particular attention to some of the implications for industrial practice, that this book has been written.

N. A. DUdLEy 


\title{
Contents
}

\author{
Preface v \\ I Introduction I \\ 2 Conventional Time Study Rating 8 \\ 3 Other Rating Techniques 24 \\ 4 Compensating Rest Allowances: Measurement of Fatigue \\ 28
}

5 Work-Time Distributions and Motion-Time Patterns 37

6 Performance Characteristics of Repetitive Work: Background and Tentative Hypotheses 48

7 Performance Characteristics of Repetitive Work: Research Procedure and Findings 59

8 Comparison of Paced and Unpaced Performance 87

9 Other Techniques

(i) Machine Interference 99

(ii) Activity Ratio Studies Ioo

(iii) Perception Study 104

Io Instruments for Work Measurement Research $\quad$ I06

Appendices Iro

References $\quad \mathrm{I} 24$

Glossary of Terms $\quad$ I30

Author Index $\quad \mathbf{1 3 7}$

Subject Index $\quad$ I39 